Prof. T. H. Pear educated and entertained a large audience concerning "The Borderland between Physies and Psychology"; he convicted of error any who still believed in the reliability of their senses, and considered how far psychology might dare to use the methods of the older sciences. Biologists found much of special interest to them at the meeting; in addition to demonstrations in the Botany and Zoology Departments dealing with genetics, ecology, the biology of injurious insects and pest-control in practice, there were lectures by Prof. H. Graham Cannon on "The Mechanics of CellDivision" and by Prof. J. Montagu Drummond on "Some Practical Applications of Botanical Seience".

There was a large attendance at a discussion on the Association's recent report on the "Teaching of General Science". The president took the chair, and Mr. C. L. Bryant (Harrow), chairman of the subcommittee which drew up the report, introduced the subject; Dr. A. W. Barton (Repton) and Mr. J. Clement Platt (Chadderton) opened the discussion. Dr. Barton addressed himself to the question, "Do we want general science?", and Mr. Platt to the question, "Is this the sort of general science we want ?" Both commended the report with minor qualifications: Dr. Barton considers that physics and chemistry are the best branches from which to learn scientific principles, and biology a good field for their application; Mr. Platt wants a better knitting of the different branches. Subsequent discussion took three main lines, which were stressed by many speakers: that the introduction set forth elearly, even brilliantly, the case for general science ; not a voice was raised against it. That the actual syllabus proposed was impractical (no speaker thought it possible to cover the ground suggested having regard to proper teaching method and due time for practical work, in four years at four periods a week; and some were emphatic that the broadsheets must be re-written); and that since four periods a week was an improperly small time for science, everything depended upon how the subcommittee's final report dealt with the rest of the time. Mr. Bryant replied wittily, and everyone awaits the final report with impatience; it can scarcely come in less than twelve months.

At the business meeting, Sir Cyril Ashfordmember of the Association since its formation in 1900 -was elected president for next year. In succession to Dr. T. J. Baker (Birmingham), Mr. J. W. Cottingham (Barnsley), Mr. W. R. B. Brooks (Lowestoft) and Mr. W. J. R. Deeks (City of London), who retired from the Committee, the meeting elected Messrs. C. L. Byrant (Harrow), W. G. Rhodes (Firth Park, Sheffield), E. M. Rogers (Charterhouse) and H. P. Ramage (Gresham's, Holt). Mr. S. V. Brown (Liverpool Institute) was re-elected general secretary, Mr. B. M. Neville (William Ellis), honorary treasurer and Mr. R. E. Williams (Department of Education, (University of Oxford), annual meeting secretary.

Between five and six hundred science masters attended the meeting, and the University spared no pains to make them welcome; a University reception followed the presidential address.

\title{
The U.S.S.R. Academy of Sciences and the Third Five-Year Plan
}

\begin{abstract}
$\mathrm{T}$ HE Russian Academy of Sciences was founded in 1725 by Peter the Great as an "assembly of the best learned men" who were supposed to carry on research, to train young men of science, and to study the country's natural resources. Under the old regime, the Academy devoted most of its energies to abstract research, surveys of natural resources and the study of Asiatic languages. Its character did not change immediately after the Revolution and it remained out of touch with the economic needs of the country for some time. The change came in 1929 when the function of the Academy was defined as the direction of the whole volume of scientific knowledge towards the reconstruetion of national economy, and a number of members of the Communist Party, distinguished in various branches of technological science, were included in the Academy. In 1934 the Academy was made directly responsible to the Government of the U.S.S.R. and its headquarters were transferred from Leningrad to Moscow, in order to bring it into closer contact with central administrative bodies, particularly with the State Planning Commission. The headquarters of the Academy, its central administrative departments and its principal research institutes and laboratories are now in Moscow, where new buildings are being built to house the various sections.

Under its new constitution, adopted in November 1935, the aims and functions of the Academy are defined thus: First, the Academy is not merely a
\end{abstract}

centre for the passive registration of scientific facts, but also an active body for the development of scientific thought. Secondly, the Academy has to study and to develop world scientific achievements with the view of applying them to the work of construction. Thirdly, the Academy has to utilize the achievements of science to further the country's progress towards a classless order of society.

The Technical Section of the Academy was charged with the duty of seeing that the results of research were introduced into industry. It has to maintain contact not only with the research institutes and laboratories of the Academy itself, but also with the various commissariats and industrial enterprises. Among the groups now functioning under the Technical Section are those dealing with power, mining, technical physics, technical chemistry, technical mechanics, automatic processes and telemechanics.

Another function of the Academy is to study the natural resources and productive forces of the country, and to promote their rational utilization. For a number of years, the Council for the Study of the Natural Resources of the U.S.S.R. has been sending out expeditions for these purposes. Branches of the Academy have been established in various parts of the country to direct the work of prospecting and surveying. The first preliminary general survey of the geological, chemical and economic resources 
has already been completed. Now, with the approach of the Third Five-Year Plan, the activities of the Academy in this field are to undergo a decided change. Attention will be concentrated on key positions, and the number of the Academy's branches will be reduced, or handed over to the local authorities. A further function of the Academy is to study the cultural and economic achievements of mankind and to help in their rational application for the building-up of the new society. The main responsibility for this work falls upon the Social Sciences Section.

The work of the Academy in the immediate future is to aid the State Planning Commission in the drawing up of the Third Five-Year Plan. The main efforts of the Academy's various institutes will be directed towards the solution of the following ten problems, outlined at a session held last March. (Needless to say, these problems do not comprise the whole work of the Academy and its research workers but, for the moment, they are the leading and dominant ones.)

(1) To develop geological, geochemical and geophysical methods of prospecting for useful minerals, particularly tin, rare metals and oil.

(2) To solve the problem of power by creating a unified electric power system throughout the U.S.S.R., with high-voltage transmission.

(3) To rationalize and extend the use of natural gas and by-product gas from industrial plants.

(4) To find a new type of fuel for internal combustion engines (study of chain reactions and explosion processes, internal combustion motor and electric automobiles).

(5) To rationalize technological processes in chemistry and metallurgy.

(6) To help in raising the grain yield of the country (research in seed selection, soil chemistry, plant biology, fertilizers and the mechanization of agriculture).

(7) To establish scientific bases for the development of animal husbandry and fisheries.

(8) To develop telemechanics (long-distance control of machinery) and to extend automatic processes in industry through application of theoretical physics.

(9) To draw up the balance sheet of the national economy of the U.S.S.R. so as to serve as a scientific basis for the Third Five-Year Plan.

(10) To study the history of the peoples of the U.S.S.R.

\section{Science News a Century Ago}

\section{Robert Macnish (1802-37)}

Dr. RoBert Macnish, a brilliant physician and man of letters, who died on January 16, 1837, was born at Glasgow on February 15, 1802, the son and grandson of medical men. He obtained the degree of master of surgery at the early age of eighteen years, and first served as assistant to a general practitioner for eighteen months. $\mathrm{He}$ then went to Paris, where he attended the lectures of Broussais and Dupuytren and made the acquaintance of Gall, who pointed out Macnish to his fellow students as presenting a remarkable development of the organ of comparison.

On his return to Glasgow in 1825, Macnish obtained the degree of M.D. with a thesis on "The Anatomy of Drunkenness", which was published in
1827. Enlarged editions afterwards appeared and enjoyed a wide popularity. The work is of some historical value as being the first attempt to study drunkenness in its physiological aspects rather than as a crime. Macnish's next most important medical publication was "The Philosophy of Sleep", and was mainly based on the doctrines of Gall. His interest in phrenology is further shown by the publication in 1836 of an elementary treatise on the subject in the form of question and answer. At about the same time, he brought out a new edition of Amariah Brigham's "Remarks on the Influence of Mental Cultivation and Mental Excitement upon Health", to which he added numerous notes. He also contributed numerous articles to various periodicals, the best known of which, published in Blackwood's Magazine, was the tale entitled "Metempsychosis", which he wrote under the nom de guerre of "Modern Pythagorean". His collected tales, essays and sketches were afterwards published under this title with an account of his life by his friend Dr. David M. Moir. His premature death was due to an attack of influenza.

\section{Production of Minerals in France}

AT a meeting of the Statistical Society held on January 16, 1837, a paper by the chairman, G. $R$. Porter, was read entitled "A Statistical Account of the Mineral Products obtained in France during the year 1834; taken from official documents". In his opening remarks, the author said, that though in Great Britain no systematic effort had been made to gather statisties on the iron and coal mines, the French Government had recently deputed M. Le Play to ascertain the capability of every iron works and nearly every coal-field in England.

Mr. Porter's review of the mineral resources of France was divided under the following heads : ironworks; fuel ; metals; salt, alum and copper ore; quarries, and operations connected with mineral substances. The quantity of iron ore obtained in France in 1834 was 1,551,473 tons, the number of smelting furnaces 374 and the weight of iron produced 221,886 tons. There were in use 97 furnaces for converting ore at once into malleable iron and steel, by a peculiar process used in Corsica, the production being 8,531 tons of iron and 399 tons of steel. There were also 1,230 forges for converting cast into malleable iron, and 1,556 rolling, drawing and slitting machines. The total value of the French iron manufacture was $£ 3,492,519$, and the number of men employed 31,704. Five sixths of the fuel used in iron manufacture came from the French forests. During 1834, 140 coal mines were being worked, and the coal produced was 1,550,530 tons.

George Richardson Porter, the author of the paper, was born in 1792 and died in 1852. Failing in business as a sugar-broker, he devoted himself to economics and statistics, and the Statistical Department of the Board of Trade was established mainly under his supervision. Among his writings was "The Progress of the Nation from the Beginning of the Nineteenth Century", the third edition of which appeared in $185 \mathrm{l}$.

\section{Rev. Baden Powell on the Dispersion of Light}

Aт a meeting of the Royal Society held on January 19, 1837, the Rev. Baden Powell, then Savilian professor of geometry at Oxford, read a paper entitled "Researches towards establishing a Theory of the Dispersion of Light". An abstract of the paper said : 